\title{
LIMITATION OF THE RIGHT TO FREEDOM OF SPEECH ON THE INDONESIAN CONSTITUTIONAL COURT CONSIDERATION
}

\author{
Titis Anindyajati \\ The Indonesian Constitutional Court \\ JI.Medan Merdeka Barat No.6 Jakarta Pusat, 10110 \\ e-mail: titis.anindya79@gmail.com
}

\begin{abstract}
Nowadays, everyone tends to use the right to freedom of speech without limitation, such as emergences of hate speech expression on various social media platforms. However, such expression is regulated by Article 28, paragraph (2) of the ITE Law and deemed to be contrary to public order. On the other hand, this law was considered by some people as a criminalization towards the right to freedom of speech. This paradox becomes a big issue that never ceases to be discussed. That is why Constitutional Court had conducted judicial review on some norms related to freedom of speech. This study aims to analyze the Constitutional Court decision towards the polarity of the right to freedom of speech and the public order. This study uses normative research with the statutory, analytical and comparative approach. Therefore, the results show the importance of limitation in implementing the freedom of speech to protect the constitutional right of society as stated in the 1945 Constitution. Despite the already decided judicial review by the Court, there is still an urgency to revise The ITE law in order to clarify certain rules related to hate speech in social media.
\end{abstract}

Keywords: Constitutional Court, freedom of speech limitation, public order, Constitutional Rights

\section{A. Introduction}

Freedom of expression is an integral part of a democratic law country. In a democratic country, human rights' protection, particularly the freedom of speech, should have been guaranteed and regulated. The right to freedom of speech as part of the freedom of expression is one of the main elements of acknowledging the people's sovereignty in a democratic country. As a constitutional democratic country, Indonesia upholds the protection of human rights that is proven by regulating the right to freedom of speech in Article 28E paragraph (3) of the 1945
Constitution and ratification of the Universal Declaration of Human Rights (UDHR). Moreover, the regulation of freedom of opinion had specifically existed in a separate law, namely Law Number 9 of 1998 on Freedom of Speech. Although this law does not control the expression of opinions through the mass media, both printed and electronic, this law guarantees the rights of every citizen to express their thoughts orally and in writing freely and responsibly subject to the provisions of the prevailing rules and regulations. 
Along with the development of information technology and the emergence of social network freedom and accessibility, people had more freedom and access to easily express their freedom of speech and opinions. In this paper, the freedom to express views is focused on the freedom to express opinions in social media. The revolution in communication through social media, especially the massive online social media platform, has created a new technology phenomenon. Nowadays, people tend to use social media as the main instrument in communicating and expressing their opinions. The Ministry of Communication and Informatics of Indonesia revealed that internet users in Indonesia currently reach 63 million people. Out of these, 95 percent use the internet to access social networking. According to the Director of International Information Services at the Directorate General of Information and Public Communication of the Ministry of Communication and Information Technology, Selamatta Sembiring, Indonesia is ranked 4th for Facebook users and in the 5th largest Twitter user in the world. ${ }^{1}$ Another fact that is also very interesting is that the types of social media that are most often used in Indonesia, namely, YouTube, WhatsApp, and Facebook are in the top three rankings.
Table 1. The rank of The Most Often Used social media ${ }^{2}$

\begin{tabular}{|c|c|c|}
\hline No & Media social & Amount (\%) \\
\hline 1 & Youtube & 88 \\
\hline 2 & WhatsApp & 84 \\
\hline 3 & Facebook & 82 \\
\hline 4 & Instagram & 79 \\
\hline 5 & Twitter & 56 \\
\hline \multicolumn{2}{|c|}{ source: katadata.co.id (2020) }
\end{tabular}

However, even though YouTube is in the first place for the most used, according to the data in a report released by SafeNet (Southeast Asia Freedom of Expression Network), the social media most often used by perpetrators in committing internet-related crimes, namely Instagram (534 cases), WhatsApp (431 cases) and Facebook (304 cases). ${ }^{3}$ Matters related to crimes against freedom of speech are pretty attention-grabbing because the perpetrators in Instagram are public figures, for example, the case experienced by I Gede Ari Astina or often called Jerinx. The drummer for Superman Is Dead was sentenced to one year and two months imprisonment and a fine of 10 million Rupiah in the case of " IDI (Indonesian Doctor Association) lackeys of WHO ". The Panel of Judges at the Denpasar District Court (PN) found Jerinx guilty of spreading information to show hatred towards specific individuals or groups based on ethnic groups, religions, races,

1 Kementerian Komunikasi dan Informatika Republik Indonesia, "Kominfo:Pengguna Internet di Indonesia 63 Juta Orang," Kementerian Komunikasi dan Informatika (kominfo.go.id), (accessed 30 March 2021).

2 Katadata, "10 Media Sosial yang Paling Sering Digunakan di Indonesia," https://databoks.katadata.co.id/ datapublish/2020/02/26/10-media-sosial-yang-paling-sering-digunakan-di-indonesia, (accessed 20 March 2021).

3 Safenet, “Laporan Situasi Hak-hak Digital Indonesia 2019,” https://s.id/lapsafenet2019, (accessed 20 March 2021), p.25. 
and intergroups.

Jerinx's case is not the first. There are several perpetrators of criminal acts against freedom of speech, as quoted from the SafeNet complaint and monitoring data on media coverage from January to October 2020. There were at least 59 cases of convictions against netizens. Out of these, 14 people (31 percent) were charged under Article 28, para. 2 of the Information And Electronic Transaction Law (ITE Law $)^{4}$. Article 28 para. (2) states, "Any Person who knowingly and without authority disseminates information aimed at inflicting hatred or dissention on individuals and/or certain groups of community based on ethnic groups, religions, races, and intergroup (SARA)." This article can cause difficulties in its implementation because it contains vague Norment rules in the concept of "intergroup". The article does not provide an unambiguous explanation regarding the meaning and criteria of the concept of "intergroup" so that the article can lead to different interpretations, which can be interpreted broadly or narrowly. ${ }^{5}$

The number of criminal cases usingArticle 28, para. (2) of the ITE Law is a paradox for the ITE Law's Spirit. The ITE Law was issued in 2008 during the administration of President Susilo Bambang Yudhoyono (SBY) as a response and a form of state responsibility in national development through the use of information technology. This law is a government attempt to provide explicit and legally binding protections against various kinds of negative electronic transactions. Therefore, forms of legal violations in electronic trading transactions and legal actions in cyberspace are now a worrisome phenomenon with the emergence of carding, hacking, cracking, phising, pornography, and dissemination of destructive information of how to treat internet crimes. ${ }^{6}$ However, at that time, the draft of the ITE Law received a lot of criticism from the public. One of the reasons is that what should be regulated to affect the technology on the lives of citizens and not the technology that is dynamically developing. ${ }^{7}$ Therefore, several problems to the catchall articles in the implementation had a severe impact that had never been predicted before, either by the legislators, the law enforcers, and the society itself.

The development and advancement of information technology are very rapid and provide a direct and significant response. There are changes in human activities covering almost all aspects, such as economic, legal, social, and cultural. However, as stated in the general explanation of the ITE Law, legal issues that often arise

$4 \quad$ Safenet Voice Rilis Pers, "Hentikan Pelintiran Pasal Ujaran Kebencian dan Frasa "Antargolongan" Untuk Membungkam Ekspresi," https://id.safenet.or.id/2020/11/rilis-pers-hentikan-pelintiran-pasal-ujarankebencian-dan-frasa-antargolongan-untuk-membungkam-ekspresi/(accessed 20 March 2021).

5 Tiara Kumalasari. “Konsep “Antargolongan” dalam Pasal 28 Ayat (2) Undang-Undang Nomor 19 Tahun 2016 Tentang Perubahan atas Undang-Undang Nomor 11 Tahun 2008 Tentang Informasi Dan Transaksi Elektronik (UU ITE)". Media Iuris Vol. 3 No. 2 (2020),p.204-205.

6 Raida L Tobing et al., Efektivitas Undang-Undang Nomor 11 Tahun 2008 tentang Infromasi dan Transaksi Elektronik (Jakarta:Badan Pembinaan Hukum Nasional Kementerian Hukum dan HAM,2012),p.6.

7 Tobias Basuki,et.al., "Unintended Consequences: Dampak Sosial dan Politik UU Informasi dan Transaksi Elektronik (ITE) 2008". (Jakarta: CSIS Working Paper Series WPSPOL, 03/2018), p.8. 
are related to the delivery of information, communication, and electronic transaction, especially in terms of evidence and matters on legal acts carried out through electronic systems. It has not been adequately realized by the public regarding the impact on easy access to technological advances, particularly in terms of social media use. The public cannot distinguish the boundary between private and public aspects in the right to freedom of expression. Sometimes, their opinions may violate the law without realizing it. The activity of disseminating information to create hatred or hostility to specific individuals and/or groups of people based on ethnic groups, religions, races, and intergroup (SARA) through social media is a violation of the law related to the delivery of information and lor communication via electronic systems.

The provisions of Article 28 para. (2) the ITE Law was petitioned for review to the Constitutional Court in 2017 by an individual applicant who is an advocate in Case Number 76/PUU-XV/2017. The Petitioner explained that the provisions of Article 28 para. (2) and para. 45A (2) of the ITE Law can be used to criminalize the petitioner in issuing an opinion due to the unclear definition of the word "intergroup". They believe that because of the indefinite boundaries of the term "intergroup", activists who have issued opinions in the form of criticism to the government through social media have reportedly violated Article 28 para. (2) and para. 45A (2) of the ITE Law several times. Even though the activist did not make statements that provoked hatred based on ethnic groups, religions, or races, he was accused of causing group-based hatred. Eventually, it will create difficulties for the public to express their opinion because they are at risk of getting into legal trouble.

In its decision, the Court providing an explanation and meaning of the concept of "intergroup", which the applicant considers unclear and multiple interpretations, causing injustice in its application, primarily related to Article 28 paragraph (2) and Article 45A paragraph (2) of the ITE Law. The Court explained that when a statutory regulation is applied arbitrarily, such a thing is terrible and dangerous. However, it is not a problem of the constitutionality of norms but a problem of law enforcement, for which there are legal remedies to deal with it. The Constitutional Court believes that freedom of opinion, including the spread of information orally or through specific media, needs to be limited by the obligation to respect the human rights of others as stipulated in Article 28J paragraph (1) of the 1945 Constitution. Respect for the human rights of others is essential to be implemented in addition to the constitution stipulated. It also aims at public order in a constitutional democracy.

Most of the research related to freedom of opinion tends to agree with the existence of freedom as a whole and calls for a revision of the ITE Law because many catchall articles lead to the criminalization of the right to freedom of speech by Indonesian citizens. For example, the research of Vidya Prahassacitta and Batara Mulia Hasibuan (2019) entitled Disparity Freedom of Expression Protection in The Implementation of Defamation Article in Information and Transaction Electronic Law: An Analysis of 
Court Decisions Year 2010-2016 Period. They analyze the formulation of the problem of how inconsistent the application of the defamation article in Article 27 paragraph (3) juncto Article 45 of Information and Electronic Transactions Law, along with the aspect of freedom of expression protection through the district court decisions around the period 2010-2016. ${ }^{8}$ Marwandianto and Hilmi Ardani Nasution's (2020) research entitled The Rights to Freedom of Opinion and Expression in the Corridors of Article 310 and 311 of KUHP (the criminal law code). This research concludes that the proper formulation regarding the implementation of law related to freedom of opinion and expression, namely the performance, must be carried out sufficiently and proportionally. ${ }^{9}$ The implementation other than punishment needs to be encouraged by law enforcers to prevent the disruption of freedom of opinion and expression in Indonesia. Next is the research conducted by Iman Amanda $P$ and Junior Hendri Wijaya (2019) entitled Implementation of Electronics Information and Transaction in Completion of the Problem of Hate Speech on Social Media. This research examines the implementation of the ITE Law, which is under the objectives of the 1945 Constitution. However, it is always bound to the catchall article in solving the hate speech issue, namely articles 27,28 , and 29 of the ITE Law. ${ }^{10}$ However, only a few studies are examining how the Constitutional Court responded to questions regarding the constitutionality of restricting the freedom of expression in the ITE Law related to aspects of public order.

As a constitutional democracy based on the constitution, the state guarantees its citizens' rights of speech. Even though freedom of expression is an expansive provision, it is still necessary to carry out restrictions in its implementation to protect other rights [vide Art.28J para.2]. However, the constitution limits the freedom of speech $t$ to keep in line with the morality, religion, values, security, and public order principle as a Syracuse principle (1985) does. ${ }^{11}$ Therefore, this study objects to analyze how the consideration decision Constitutional Court's on the polarity of the right to freedom of opinion and the public order principle as one of the state's goals as stated in the preamble to the 1945 Constitution.

\section{B. Research Method}

This study uses a normative legal research method because it uses the basis for considering a judge's decision that contains legal principles or legal doctrines used as a basis for consideration (ratio decidendi) to arrive at an (obiter dicta). It also uses a statute, comparative, and analysis approach.

$8 \quad$ Vidya Prahassacitta dan Batara Mulia Hasibuan. "Disparitas Perlindungan Kebebasan Berekspresi Dalam Penerapan Pasal Penghinaan Undang-Undang Informasi Dan Transaksi Elektronik: Kajian Atas Putusan Pengadilan Periode Tahun 2010-2016". Jurnal Yudisial, Vol 12 No 1 (2019), p.61-79.

9 Marwandianto dan Hilmi Ardani Nasution. "The Rights to Freedom of Opinion and Expression in The Corridors of Article 310 and 311 of KUHP". Jurnal HAM Volume 11, Nomor 1 April (2020), p. 1-25.

10 Iman Amanda P dan Junior Hendri Wijaya. "Implementasi Undang-Undang Informasi dan Transaksi Elektronik Dalam Penyelesaian Masalah Ujaran Kebencian Pada Media Sosial”. Jurnal Penelitian Pers dan Komunikasi Pembangunan, Vol.23 No.1 (2019), p.27-42.

11 R.Herlambang Perdana Wiratraman. "In Search of Constitutionality: Freedom of Expression And Indonesia's Anti-Pornography Law". Jurnal Yuridika, Vol.7 No.2 (2012), p.111-118. 
Statute approach analyses the law and the 1945 constitution and the regulations related to the freedom of speech and its limitations. A comparative approach is to compare the regulation of freedom of speech and its boundary with other countries. this research will use some countries that have similarities with Indonesia, that regulate the limitation of freedom of speech in their constitution. Meanwhile the analytical approach analyses the Court decisions related to the ITE Law and the constitutionality of freedom limitation, such as decision Number 76/PUU-XV/2017, Number 065/PUU-II/2004, etc.

The primary source of data in normative legal research is library data or also known as legal materials. The legal materials studied and analyzed consist of primary legal materials such as the 1945 Constitution and the international and national laws such as UDHR, ICCPR, ITE Law, human rights law, and other laws. Then, secondary legal materials such as books, journals, and working papers related to the freedom of speech and tertiary legal materials such as the sizeable Indonesian and English dictionary. ${ }^{12}$

\section{Discussion}

\section{Freedom of Speech Limitation: Public Order and Constitutional Right}

Freedom of speech comes from the word free (freedom), which is freedom or the state of freedom. Meanwhile, speech is to speak, to say, to have a conversation, to utter a language, to give birth to opinions, and to confer (by word, writing, etc.). ${ }^{13}$ Thus freedom of speech is the freedom of opinion (by word, writing, etc.). Speaking of freedom of speech should have related to the hate speech. Unfortunately, hate speech is very ambiguous since there is no clear definition given by the law about freedom of speech, particularly for hate speech. The law only gives the criteria of limited freedom of speech without any specific explanation of what freedom of speech or hate speech is. Gavan Titley mentioned that there is no consensus on what constitutes hate speech and the differences that are manifested in legal and regulatory approaches in different countries. ${ }^{14}$ According to Herlambang P. Wiratraman, hate speech in Indonesia's juridical basis originally from the Netherlands Indies' penal code known as "haatzaai artikelen", which means 'hate speech' or 'hatred sowing' (ujaran kebencian in Indonesian). There are three classifications of hate speech in Indonesia law. First, hatred against the government and country badge [Art 154 and Art 155 Penal Code], the second, hatred against a person or the public [Art 156 and Art 157 Penal Code], the third, hate speech in digital media [Art 28 para 2 ITE law]. ${ }^{15}$

12 Salim etal., Penerapan Teori Hukum Pada Penelitian Tesis dan Disertasi (Jakarta:PT RajaGrafindo Persada,2017), p.17-8.

13 Tim Penyusun Kamus Bahasa Indonesia, Kamus Besar Bahasa Indonesia, (Jakarta: Pusat Bahasa Departemen Pendidikan Nasional, 2008), p.153\&p.196.

14 Gavan Titley, "Hate Speech Online: considerations for the proposed campaign", Council of Europe, 2014, https://rm.coe.int/1680665ba7 (accessed May 25, 2021), p.9

15 Herlambang P. Wiratraman and Sebastien Lafrance. "Protecting Freedom of Expression in Multicultural Societies: Comparing Constitutionalism in Indonesia and Canada”. Jurnal Yuridika, Vol.36 No.1 (2021), p.75120. 
Therefore, the issue of hate speech in Indonesia should be analyzed, whether it is about implementing the norm or the right that should be protected. That is why many judicial reviews related Article 28 para (2) to Constitutional Court. As an authorized institution, the Constitutional Court legally has the authority to interpret the meaning of the provisions contained in the constitution. This interpretation is binding when the Court issues a decision of the Constitutional Court on the petition submitted to it.

Because Indonesia has ratified ICCPR and DUHAM, there must be an equivalence concept about hate speech in ITE law and ICCPR. These ITE law, DUHAM, and ICCPR principally protect all the subjectivity ideas and opinions that spread to other people by giving some limitation. The limitation of freedom of speech in Indonesia is stipulated in Article 28J para.2 of the Constitution that explicitly provides the limitation with parameters. Meanwhile, Article 19 para. 3 and Article 20 ICCPR regulates the restriction of freedom of speech. Fundamentally, everyone has the right to freedom of expression, but it carries special duties and responsibilities. In conclusion, the limitation of freedom of speech based on the Indonesian constitution and ICCPR has the similarity, that is to protect the public order and to respect other people's rights.

However, in the United States, both Judge Oliver Wendell Holmes and Scholars Robert
Post believe that America's first amendment can limit freedom of speech without violating the constitution. The meaning in the first amendment of America is not limited to syntax, semantics also has its values. ${ }^{16}$ It means that in a democratic country such as America, the right to freedom of speech is possible to implement. Alexander Tsesis explained that, however, in a pluralist society, they must protect freedom of speech and protect the principle of respect for the dignity of others. Public policy does not condone hate speech which results in a violation of peace or public order. The Supreme Court has found that the government has a countervailing social interest in order and morality that justifies speech limitations.

The Supreme Court has found that the government has a countervailing social interest in order and morality that justifies some limitations on speech. ${ }^{17}$ Moreover, sustaining public order becomes another social value of government to countervail the freedom of speech. A state can promulgate narrowly tailored criminal regulations against intimidation that threatens public safety to protect democracy. In combating the threat of hate speech, the states committed to adopting laws that prevent the dangerous dissemination of messages without interfering with legitimation. ${ }^{18}$ There are several cases that the state uses the concept of public order to restrict expressions. For instance, the Pakistani Supreme Court

16 Alexander Tsesis, “Dignity and Speech: The Regulation of Hate Speech in a Democracy,” Wake Forest Law Review (2009), https://lawecommons.luc.edu/cgi/viewcontent.cgi?article=1040\&context=facpubs (accessed 10 April 2021), p.498.

17 Alexander Tsesis, "Dignity and Speech: The Regulation of Hate Speech in a Democracy," Wake Forest Law Review (2009), https://lawecommons.luc.edu/cgi/viewcontent.cgi?article=1040\&context=facpubs (accessed 10 April 2021), p.498. Ibid.p.501. 
postulated that the public expressions of the Ahmadi community banning the public display of Kalimah and claiming that they are 'moslem' would provoke outrage among the Sunni majority based on public order [case of Zaheeruddin v. State (1993)]. The other example is the Chile government restricting the expression of the fortieth anniversary of the military coup d'etat by removing the banners to prevent potential disruption to public order arising out of the burning of the banners [case of Claudia Andrea Marchant Reyes et al. v. Chile (2017)] ${ }^{19}$.

In Indonesia, the Article 28E para.3 1945 Constitution regulates 3 (three) kinds of constitutional rights: freedom of association, freedom of assembly, and freedom of opinion. However, the freedom of speech as a human right also includes a constitutional right in the Constitution of Indonesia. A Constitutional right is a right related to the human rights guaranteed in the 1945 Constitution. According to Jimly Asshiddiqie, not all constitutional rights are human rights, but all human rights are the constitutional rights of citizens. Meanwhile, the difference between constitutional rights and legal rights is that legal rights arise based on guarantee of laws and statutory regulations under them. In contrast, constitutional rights are rights guaranteed in and by the 1945 Constitution. ${ }^{20}$

Article 28J para. 2 states that in exercising their rights and freedom, everyone should conform to any restrictions established by law solely to ensure the recognition and respect for the rights and freedom of others and fulfilling the morality, religious values, security, and public order in a democratic society. Thus, there should be an obligation to respect others' personal rights and freedom. The duty to respect others' rights is needed to balance the public interest and the individual or the community's rights. Therefore, both the United States constitution and the Indonesian Constitution included freedom of speech as a constitutional right. Yet, there should be a limitation in implementing the right itself to protect the public order.

Since Indonesia ratified the Human Rights Declaration and the ICCPR, several norms regulate the right to freedom of speech in Indonesian laws and regulations, including:

a. Article 23 paragraph (2) and Article 73 of Law Number 39 of 1999 on Human Rights.

b. Article 2 of Law Number 9 of 1998 on Freedom of Speech

c. Law Number 40 of 1999 on the Press

For the Press to function optimally as mandated by Article 28 of the 1945 Constitution, it is necessary to establish a law on the press. In carrying out its functions, rights, obligations, and roles, the press respects everyone's human rights. Therefore it demands a professional and open press that is controlled by public.

d. Articles 4 and 16 of Law Number 40 of 2008 on the Elimination of Racial and

19 Gehan Gunatilleke, "Justifying Limitations on the Freedom of Expression," Human Right Review (2020), Justifying Limitations on the Freedom of Expression | SpringerLink (accessed 12 April 2021), p.100.

20 Jimly Asshiddiqie, Pokok-Pokok Hukum Tata Negara Indonesia (Jakarta:PT Bhuana Ilmu Populer,2007), p.6167. 
Ethnic Discrimination also prohibit racial discrimination.

Whereas the law mentioned above contains the rights to freedom of expression, the norms are also followed by several restrictions on these rights. As long as an individual's rights also have a relationship with the obligations of others, these rights are relative and not absolute. Quoting Masyhur Effendi's opinion, human beings cannot be separated from the legal system that applies at a particular time. Therefore, humans must always be reminded of the nature of having a state, living in society as befits a subject of the law that is limited by the rules of the law in force. Therefore, the implementation of human rights is never absolute and is bound by formal rules, namely rules that respect the existence of human rights themselves. ${ }^{21}$ However, the state has the responsibility to protect the citizen's constitutional rights as stated in Article 281 para. (4) the 1945 Constitution, the states simultaneously imposing restrictions on the fulfillment of rights and the obligations of its citizens. The states can intervene in the right to free speech in certain circumstances as stipulated in Article 4 of the ICCPR.

Moreover, the spirit in Article 19 UDHR is freedom of opinion for some countries is considered enormous. Later, ICCPR reconstructing with the addition of a paragraph in Article 19 of the ICCPR, namely the exercise of the rights. Provided in para. 2 of this article carries with it special duties and responsibilities. It may, therefore, be subject to certain restrictions, but these shall only be such as are provided by law and are necessary: (a) for respect of the rights or reputations of others, (b) for the protection of national security or public order, or of public health or morals. The right to freedom of expression is a Derogable Right, namely rights that can be reduced or limited by the state. States parties to the ICCPR are allowed to concentrate or deviate from their obligations to fulfill these rights. Still, such variations can o nly be made if they are proportional to the threat that disturbs national security or the emergency faced and do not discriminate against races and ethnic groups. Never theless, freedom of speech is a constitutional right guaranteed by the state; it can reduce as long as it is to achieve the state's goals, one of which is to protect the entire Indonesian nation and public order. In their research, the Institute for Criminal Justice Reform (ICJR) explained that restrictions on the right to raise an opinion and expression are permitted if it is the only way to achieve the objectives, and objectives of protection by the ICCPR. Nevertheless, the limitation of rights must be proportional or not excessive. Pr o portionality when drafting laws that impose its implementation in the administrative framework and a judicial application. The principle of proportionality is used to assess expressions, the process of dissemination, and outreach to the public. ${ }^{22}$

One of the laws' nature is that the law can be enforced beca u se it contains an obligation that the law-abiding person must 
conduct. As the equivalent of obligations, law and the state guarantee the rights of citizens. Therefore, the state can interfere with the duties and rights of its citizens. Coercion, responsibility, and rights on citizens to uphold a system of order designed by law or also known as the concept of public order. ${ }^{23}$

Thus, in the context of efforts to prevent disorder in all walks of life due to nonfreedom without rules, it is necessary to place restrictions on freedom, particularly freedom of speech in Indonesia. Freedom becomes valuable if it is accompanied by efforts to respect the rights and dignity of others to create public order and maintain the unity and integrity of the Indonesian nation. It is in line with constitutional values and the goals of the Indonesian state as stated in the 1945 Constitution and Pancasila.

\section{The Freedom of Speech in Several Countries}

According to Ronald Leenes et al., in the new millennium, many countries have issued policy documents to promote information society, e-commerce, e-government, and stimulating the new media. Noticeable in these initiatives is an emphasis on facilitating universal access (e.g., Sweden, France, U.S., Canada), guaranteeing and promoting access to public information (Sweden, Germany, France, U.S.), and self-regulation as a significant way of regulating the internet and new media (France and U.S.), indicating a limitation for state intervention. Therefore, most countries are protecting fundamental rights, but the role of protection partly depends on whether there is a constitutional review by the courts. ${ }^{24}$

The latitude of freedom of speech is broad. Thus, this study finds similarities between Indonesia and several countries that regulate restrictions on freedom of speech in their constitutions, among others, Sweden, France, and Germany. Furthermore, the hate speech issue became an intensely political problem across Europe. ${ }^{25}$ In Germany, for instance, the freedom of speech is regulated in Art 5, paragraph 1 and 2 of the Basic Law of the Federal Republic of Germany of 1949. But these rights are limited by the provision of the general laws, the provisions of law for the protection of youth, and by the right to inviolability of personal honor.

Another example is Sweden which has amended Article 2:1 of the Regeringsform 1974 to read "The Freedom to communicate information and to express ideas, opinions, and emotions, whether orally, in writing, in pictorial representations, or in any other way". Sweden also introduced the fundamental law on freedom of expression in 1991 as part of its constitution. ${ }^{26}$ There was a similarity between Sweden and Indonesia; Article 20 and Article 21 of the Sweden Constitution limit freedom of speech. Meanwhile, the French protection of freedom of speech is based on lower legislation and active courts.

UU ITE di Indonesia (Jakarta:Institute for Criminal Justice Reform (ICJR),2021), p. 25.

Munir Fuady, Teori-Teori Besar (Grand Theory) Dalam Hukum (Jakarta:Kencana Prenada Media Group, 2013),p.105.

24 Susan W. Brenner et al. Constitutional Rights and New Technologies: A Comparative Study (The Netherlands: T.MC.Asser Press, 2008),p.6-7.

25 Gavan Titley, Ibid.,p.7.

26 Susan W. Brenner, Ibid.,p.8. 
The Council d'Etat (high advisory board to the government), in a 1998 advice, proclaimed that radical changes in legislation as a result of internet developments were nonessential ${ }^{27}$. The French Constitutional Right to freedom of expression is recognized the accessible communication of thoughts and opinions as one of the most critical human rights, specifying that every citizen can speak, write, or print freely, being responsible for the abuses established by the law (Art.11 Declaration of the Rights of Man and the Citizen).

HerlambangP.WiratramanandSebastien Lafrance research about The Comparison Constitutionalism Freedom of Expression in Multicultural Societies between Indonesia and Canada (2021) gives new insight on how besides the similarity regulation of freedom of expression in the constitution as multicultural countries, there are differences of approach or influence on judicial decisions. ${ }^{28}$ Thus, the freedom of expression is interpreted scarcely. On the other hand, in Canada, the freedom of expression is interpreted predominantly because the Supreme Court has a particular goal to unify and strengthen the multiculturalism bond. In Indonesia, the term of political discourse is freedom of expression forms customarily neglected by law enforcers. In some cases, the political speech assumed as expressing the will of insurgents or separatist. Furthermore, the religion-based pressure aspect has a significant impact on judicial decisions. The limitation is justified proportionally based on the reasonable law evidence in the democratic society ${ }^{29}$. Therefore, those comparisons are not the same object as the researchers also said. The freedom of expression in Indonesia should be interpreted as restricted because the implementation tends to spread hatred against people and government and eventually potentially destroy the unity and multiculturalism of Indonesian society. Herlambang P. Wiratraman quoting Cherian George, who named hate speech as hate spin, believes that several hate-spins configurations are precisely using religion to threaten certain groups and get support from people. ${ }^{30}$

General freedom of expression is thus recognized, leaving the legislator to limit its exercise according to other constitutional principles and values. Thus, general freedom of expression is recognized, leaving the legislator to limit its exercise according to other constitutional principles and values. ${ }^{31}$ It can terminate that even though the freedom of speech is fundamentally regulated in the state constitution, it is not an absolute right. It is because freedom of speech is classified as derrogable right. In some democratic countries, the necessity of respecting the right of each other and public order becomes the priority issue in the implementation of right to freedom of speech.

\section{The Court's Deliberation on the Right to Freedom of Speech}


Freedom of speech is one of the human rights guaranteed by the constitution, but it requires limitations regulated in the constitution. Indonesian law prohibits actions that create hatred or hostility towards groups using any media, including online media. The regulation of hate speech in the Article of the Criminal Code Law and the ITE Law is still quite broad in defining the intent of hatred, so it must be interpreted referring to the definitions in various formulations of human rights norms. It prevents the use of the norm excessively and easily religious expressions that are considered hostile and encourage hatred. Moreover, Article 28, para. (2) of the ITE Law is considered to criminalize the right to freedom of speech in Indonesia. Furthermore, related to the criminal act of defamation, it has been regulated separately in Article 310 and Article 311 of the Criminal Code. The Criminal code rules related to defamation and slander in the Criminal Code have different dimensions. In Article 28 para. (2) of the ITE Law, there is an emphasis on the phrase "creating a sense of hatred or enmity for individuals and/or certain groups of society based on ethnic groups, religions, races, and intergroup (SARA)", which is not regulated rigidly by the Criminal Code. This provision is a prerequisite to prevent divisions and to maintain the unity and integrity of the Indonesian nation. The phenomenon of hate speech against a group increases with the ease of access to social media.

The Information and Electronic Transaction Law, which consists of 13 chapters and 57 articles, a new legal regime to regulate cyberspace activities in
Indonesia, contains several aspects, one of which is protecting the public interest. The government has the authority to protect public interests from all kinds of disturbances resulting from the misuse of information and electronic transactions that disrupt public order and national interests. ${ }^{32}$ However, in practice, the judicial review of the ITE and several laws related to freedom of expression, including freedom of speech, is often carried out by the Constitutional Court. The Constitutional Court's role as a constitutional review institution provides explanations and answers ambiguities with rational reasoning regarding the right to freedom of speech in Indonesia, particularly Article 28 para. (2) of the ITE Law.

The Constitutional Court Case Number 76/PUU-XV/2017 on Judicial Review of Article 28 para. (2) ITE Law is registered by the applicant because the phrase "group" in the article indeterminate and criminalizes some people, such as Dandhy Dwi Laksono, Ustad Alfian Tanjung, and Bambang Trimulyono. The applicants believe that expressing an opinion should be defined as criticism toward power holders unrelated to hatred based on ethnic groups, religions, and races. The spirit of guaranteeing the right to express an opinion needs legal protection from the state to the person who expresses an opinion if the party in power does not like his idea. The person who speaks that opinion should not be intimidated by those who use power. In the decision, the Court refused the petition by the reason that the issue of the term "group" is more of implementation problem, otherwise, if it is 
void, will create the uncertainty of law and rechtsvacuum. The Court believes that the use of the term/word "class" in the ITE Law and the Criminal Code indefinite because both have clear differences in context. The formulation of each article in which Article 28 paragraph (2) and Article 45A paragraph (2) of the ITE Law regulates crimes in the context of the dissemination of electronic information, while Article 156 of the Criminal Code emphasizes statements of feelings of hostility, hatred or humiliation in public. To make these provisions clearer, it is sufficient to explain through this Court decision. It is emphasized that the term "intergroup" does not only cover ethnic groups, religions, and races, but includes more than that, namely all entities that are not represented or accommodated by the terms ethnic groups, religions, and races. Thus, the Court also stressed that the meaning of "expressing an opinion" includes disseminating information both verbally and through specific media, including social media. Freedom of expression should be limited by the obligation to respect the human rights of others as stipulated in Article 28J para. (1) of the 1945 Constitution. Furthermore, the Constitutional Court provided an interpretation of Article 28 para. (2) based on the literal stipulation of Article 28J para. (2) of the Constitution, there are at least four elements of justification in limiting the exercise of rights and freedom of a person in Indonesia. Those four elements are a) determined by the law, b) guarantee recognition and respect toward the rights and freedom of others. c) fulfill a just aim under the moral, religious values, security, and public order consideration d) in a democratic society.

The cogitation of the constitutional court towards the limitation of human rights began in the Constitutional Court Decision Number 065/PUU-II/2004 on a review of Article 43 para. 1 law Number 26/2000 on Human Rights Court. The applicant stated that the implementation of the Ad Hoc Human Rights Court has the authority to examine serious human rights violations that occurred before the promulgation of the law contrary to the constitution. For this reason, the applicant, Abilio Jose Osorio Soares, former Governor of $\mathrm{KDH}$ Level I East Timor, considers that his constitutional rights have been impaired because he has been tried and punished based on retroactive legal provisions. The Court believed that the non-retroactive principle could dismiss to respect the human rights of others for the sole purpose of ensuring the upholding and respecting of the rights and liberties of others and fulfilling fair demands following moral considerations, values, religion, security, and public order in a democratic society. However, it can be applied only to extraordinary crimes and the most serious crimes of concern to the international community. In addition, the Constitutional Court uses the extent to which the public interest must be protected as the foremost consideration in assessing the constitutionality of the norms being tested. Thus, the Court declines the petition of the applicants.

Then in the Constitutional Court Decision Number 14/PUU-VI/2008 on the Review of the Criminal Code, the issue is about the constitutionality of imprisonment as regulated in Article 207, Article 310 para. 
1 and para. 2 Article 311 para. 1 and Article 316 of the Criminal Code. The Petitioner has already been legally proven to have committed defamation as stated in Article 310 paragraph (2) of the Criminal Code. The Court refuses the petitioners' petition because it includes as implementation norm than the constitutional norm issues. The Court stated that the Constitution guarantees the right to issue opinions. The state is obliged to protect these rights and protect other constitutional rights equal to the right to honor and dignity. Therefore, the state is justified in imposing restrictions on the right to freedom of expression and attitude under conscience, expressing opinions, and communicating freely. In fact, without the provisions of Article 28J para. (2) of the 1945 Constitution, each person of the right to freedom should be aware that there will always be an obligation in every right, at least the obligation not to abuse that right, especially for rights with the substance of freedom, awareness of the limitations inherent in those rights is a must.

In the legal considerations of the Constitutional Court Decision, Number 140/ PUU-VII/2009 is a review of the Law on the Prevention of Blasphemy of Religion. The reason for the petition is because some of the articles contained discrimination. After all, it had gives the state the right to determine the "interpretation of which deviating "and" deviant religious activities." It is not right for the state to do so. In addition, several articles contain the offense of "hostility", "abuse", and "defamation", as contained in Article
$156 a$ is not measurable because it is related to the process of assessing the nature, feelings of religion, religious life, and worship which is subjective. The Court declined the petition because The Blasphemy Prevention Law to be particularly important to prevent conflict between society. Furthermore, the Court believes that a universal human rights norm cannot automatically transcend philosophical values and religious values in an Indonesian and spiritual perspective as other countries can do. The Court stated that the aspect of internal freedom or the inner dimension (internum fo $r$ um) of religious freedom is absolute freedom that the state cannot interfere with. However, on another occasion, The Court locked up the debate by saying that there is a possibility to interpret freely in the internal dimension (internum forum) based on the principles of religious teachings. Therefore, there should be a limitation behind the religious right itself.

In determining what ac c ording to applicable law, the rights and obligations in positive law, the answer is always in the form of a decision. Fo $r$ this reason, the Constitutional Court $\mathrm{D}$ e cision can be an answer to the problem of conflicting rights to freedom of speech. ${ }^{33}$ The concept of the rule of law state adopted by the Republic of Indonesia puts forward the 1945 Constitution as the highest law, which must be used as a reference for all statutory regulations under it. However, some consi d erations of the Court have not been thoroughly discussed in several decisions related to the ITE Law. The Court has not explained deeply about 
the differentiated treatment towards the instrument of spreading hate speech. As explained before, there are various kinds of social media which has their characteristic. The question is whether the law enforcement officers should either treat the offender differently or the same. Therefore, it is necessary to guard and interpret the constitution to remain authoritative to establish a constitutional Court institution. As stated in Article 24 para. (1) and para. (2) of the 1945 Constitution, the Constitutional Court as the actor of judicial power and the Supreme Court established on August 14, 2003. ${ }^{34}$ As the protector of human rights and the protector of the citizen's constitutional right, the Constitutional Court shows the stance through decisions based on the 1945 Constitution.

\section{Conclusion}

It can be concluded that national law and international law essentially guarantee a person's right to freedom of expression. However, to protect the public order, the right to freedom of expression cannot be used without any restrictions. When it does, it will be considered against the 1945 Constitution and international law. The Court's stance and interpretation on freedom of speech are primarily based on the constitution and refer to universal human rights in international law, such as the UDHR and ICCPR, as additional considerations. Freedom of speech classified as a constitutional right that needs to be restricted by Article $28 \mathrm{~J}$ para. 2 of the 1945 Constitution. However, the challenge is to create certainty on the definitions and boundaries related to the implementation of these regulations.

The government and the House of Representatives need to immediately rearrange or revise the ITE Law so that the regulatory boundaries between information crime and electronic transactions in the realm or aspects and regulation of public behavior through electronic media become more intelligible. There is an immense need for guidelines on law enforcement related to implementing this regulation, especially toward various activities on various social media platforms. These guidelines are essential to creating balances between the necessity of public order and the guarantee of freedom of speech and expressing opinions in public spaces while keeping it in lieu with the constitutional aspect of the said law.

\section{Bibliography}

\section{A. Books}

1. A Budiman, Adhigama. et al, Mengatur Ulang Kebijakan Tindak Pidana di Ruang Siber:Studi Tentang Penerapan UU ITE di Indonesia (Jakarta:Institute for Criminal Justice Reform (ICJR),2021).

2. Arinanto, Satya.et al., Memahami Hukum: Dari Konstruksi sampai Implementasi (Jakarta:Rajawali Press,2009).

3. Arief Sidharta, Bernard, IImu Hukum Indonesia: Upaya Pengembangan IImu hukum Sistematik Yang Responsif Terhadap Perubahan Masyarakat (Yogyakarta:Genta Publishing,2013).

4. Asshiddiqie, Jimly, Pokok-Pokok Hukum Tata Negara Indonesia (Jakarta:PT Bhuana Ilmu Populer,2007).

5. Fuady,Munir, Teori-Teori Besar (Grand Theory) Dalam Hukum (Jakarta:Kencana Prenada Media Group, 2013). 
6. Hamidi, Jazim. et al, Teori Hukum Tata Negara: A Turning Point of the State (Jakarta:Salemba Humanika, 2012).

7. L Tobing, Raida. et al, Efektivitas UndangUndang Nomor 11 Tahun 2008 tentang Infromasi dan Transaksi Elektronik (Jakarta:Badan Pembinaan Hukum Nasional Kementerian Hukum dan HAM,2012).

8. Salim. et al, Penerapan Teori Hukum Pada Penelitian Tesis dan Disertasi (Jakarta:PT RajaGrafindo Persada,2017).

9. Tim Penyusun Kamus Bahasa Indonesia, Kamus Besar Bahasa Indonesia, (Jakarta: Pusat Bahasa Departemen Pendidikan Nasional, 2008).

10. W. Brenner, Susan. et al. Constitutional Rights and New Technologies: A Comparative Study (The Netherlands: T.MC.Asser Press, 2008).

\section{B. Paper/Article/Proceeding/ Research Result}

1. Alexander Tsesis, "Balancing Free Speech," Boston University Law Review, Vol.96 No.2(2016). https://papers. ssrn.com/sol3/papers.cfm?abstract id=2616565\# (accessed 1 March 2021).

2. Alexander Tsesis, "Dignity and Speech: The Regulation of Hate Speech in a Democracy," Wake Forest Law Review (2009), https://lawecommons.luc.edu/cgi/ viewcontent.cgi?article $=1040 \&$ context $=f a$ cpubs (accessed 10 April 2021).

3. Gehan Gunatilleke, "Justifying Limitations on the Freedom of Expression," Human Right Review (2020), Justifying Limitations on the Freedom of Expression | SpringerLink (accessed 12 April 2021).

4. Herlambang Perdana Wiratraman. "In Search of Constitutionality: Freedom of Expression And Indonesia's AntiPornography Law". Jurnal Yuridika, Vol.7 No.2 (2012). DOI: http://dx.doi. org/10.20473/ydk.v27i2.291.

5. Herlambang P. Wiratraman and Sebastien Lafrance. "Protecting Freedom of Expression in Multicultural Societies: Comparing Constitutionalism in Indonesia and Canada". Jurnal Yuridika, Vol.36 No.1 (2021).
6. DOI: 10.20473/ydk.v36i1.24032 V

7. Iman Amanda $P$ dan Junior Hendri Wijaya. "Implementasi Undang-Undang Informasi dan Transaksi Elektronik Dalam Penyelesaian Masalah Ujaran Kebencian Pada Media Sosial". Jurnal Penelitian Pers dan Komunikasi Pembangunan, Vol.23 No.1 (2019). DOI: https://doi. org/10.46426/jp2kp.v23i1.101

8. Marwandianto dan Hilmi Ardani Nasution. "The Rights to Freedom of Opinion and Expression in The Corridors of Article 310 and 311 of KUHP". Jurnal HAM Volume 11, Nomor 1 April (2020), DOI: http:// dx.doi.org/10.30641/ham.2020.11.1-25

9. Tiara Kumalasari. "Konsep "Antargolongan" dalam Pasal 28 Ayat (2) UndangUndang Nomor 19 Tahun 2016 Tentang Perubahan atas Undang-Undang Nomor 11 Tahun 2008 Tentang Informasi Dan Transaksi Elektronik (UU ITE)". Media Iuris Vol. 3 No. 2 (2020).

10. Tobias Basuki,et.al. "Unintended Consequences: Dampak Sosial dan Politik UU Informasi dan Transaksi Elektronik (ITE) 2008". CSIS Working Paper Series WPSPOL-03/2018, Jakarta, Centre for Strategic and International Studies.

11. Vidya Prahassacitta dan Batara Mulia Hasibuan. "Disparitas Perlindungan Kebebasan Berekspresi Dalam Penerapan Pasal Penghinaan Undang-Undang Informasi Dan Transaksi Elektronik: Kajian Atas Putusan Pengadilan Periode Tahun 2010-2016". Jurnal Yudisial, Vol 12 No 1 (2019), DOI:http://dx.doi.org/10.29123/ jy.v12i1.299.

\section{Internet}

1. Kementerian Komunikasi dan Informatika Republik Indonesia, "Kominfo: Pengguna Internet di Indonesia 63 Juta Orang," Kementerian Komunikasi dan Informatika (kominfo.go.id) (accessed 30 March, 2021).

2. Katadata, "10 Media Sosial yang Paling Sering Digunakan di Indonesia," https://databoks.katadata.co.id/ datapublish/2020/02/26/10-mediasosial-yang-paling-sering-digunakan-diindonesia, (accessed 20 March, 2021). 
3. Safenet, "Laporan Situasi Hak-hak Digital Indonesia 2019," https://s.id/ lapsafenet2019, (accessed 20 March, 2021).

4. Safenet Voice Rilis Pers, "Hentikan Pelintiran Pasal Ujaran Kebencian dan Frasa "Antargolongan" Untuk Membungkam Ekspresi," https:// id.safenet.or.id/2020/11/rilis-pershentikan-pelintiran-pasal-ujarankebencian-dan-frasa-antargolonganuntuk-membungkam-ekspresi/, (accessed 20 March 2021).

\section{Regulations}

1. 1945 Constitution of the Republic of Indonesia

2. Law Number 11 of 2008 on Information and Electronic Transaction

3. Law Number 19 of 2016 on Amendment of Law Number 11 of 2008 on Information and Electronic Transaction

4. Law Number 39 of 1999 on Human Rights

5. Law Number 9 of 1998 on Freedom of Speech

6. Law Number 40 of 1999 on the Press

7. Law Number 40 of 2008 on the Elimination of Racial and Ethnic Discrimination
8. The Universal Declaration of Human Rights (UDHR)

9. International Covenant on Civil and Political Rights (ICCPR)

\section{E. Court Decision}

1. The Constitutional Court Decision Number 76/PUU-XV/2017 on Judicial Review of the Law Number 11 of 2008 on Information and Electronic Transactions as amended by Law Number 19 of 2016 on Amendment to Law Number 11 of 2008 on Electronic Information and Transactions

2. The Constitutional Court Decision Number 065 /PUU-II/2004 on Judicial Review of the Law Number 26 of 2000 on Human Rights Court

3. The Constitutional Court Decision Number 14 / PUU-VI /2008 on Judicial Review of the Criminal Code law

4. The Constitutional Court Decision Number 140/PUU-VII/2009 on Judicial Review of the Law Number 1 / PNPS / 1965 on Prevention of Misuse and/or Blasphemy of Religion 


\section{Curriculum Vitae of the Author}

Titis Anindyajati, S.E., S.H., M.H. graduated from formal education: Bachelor of Economics (2007), Bachelor of Law (2018), Magister in Business Law (2010); non-formal education: Training of Research Assessors (2008), Functional Researcher Advanced Training Level at the Indonesian Institute of Sciences/LIPI (2018), Procuria Judicial Training Programmed for Legal OfficersConstitutional Court of Indonesia at De Haagse Hogeschool, Netherlands (2019). Currently, she is working as a researcher for The Deputy Chairman at the Indonesian Constitutional Court. Articles: Legal Policy of Region Enlargements According to The 1945 Constitution: An Analysis to MK Decisions (2013); The Constitutionality of Criminal Sanction Norms as Ultimum Remedium in the Making of Laws (2015); Legal Politics On the Role of the Constitutional Court In Protecting The Existence Of The Adat Law Society In Indonesia (2017); Implication of Constitutional Court Decision Number 85/PUU-XIV/2016 on Tender Conspiracy (2018). 